JEL: C32, E24, E31

Zorica Mladenović

DOI: $10.5937 /$ industrija48-29763

UDC: 331.56(497.11)

330.3(497.11)

Original Scientific Paper

\title{
Unemployment rate dynamics in small open economy: the case of Serbia
}

\author{
Article history: \\ Received: 7 November 2020 \\ Sent for revision: 14 December 2020 \\ Received in revised form: 17 December 2020 \\ Accepted: 20 December 2020 \\ Available online: 31 December 2020
}

\begin{abstract}
Dynamic relationship among unemployment rate and key macroeconomic variables is explored for the Serbian economy that has been characterized by high unemployment rates since the outcome of the Great Recession. This analysis reveals how effective policy measures can be in reducing unemployment rate. Cointegrated vector autoregressive model is employed for the period 2014-2019. Prior to multivariate dynamic modelling, the validity of hysteresis hypothesis for unemployment rate is assessed. Obtained results show significant negative long-run effect of real wages on unemployment rate, and positive long-run effect of real effective exchange rate appreciation on real wages. For further reduction of unemployment rate demand-side measures should be employed.
\end{abstract}

Keywords: unemployment, hysteresis effect, cointegration, VAR model, dynamic relationship

\section{Dinamika stope nezaposlenosti u maloj otvorenoj privredi: slučaj Srbije}

Apstrakt: $U$ radu se razmatra dinamička veza između stope nezaposlenosti $i$ ključnih makroekonomskih promenljivih u Srbiji, koju karakterišu visoke stope nezaposlenosti još od Svetske ekonomske krize. Ekonometrijska analiza ukazuje na moguću efektivnost mera ekonomske politike za smanjenje stope nezaposlenosti. Kointegrisani vektorski autoregresioni model predstavlja osnovni metodološki okvir i korišćen je za period 2014-2019. Kointegracionoj analizi prethodi ispitivanje validnosti hipoteze o histerezisu stope nezaposlenosti. Dobijeni rezultati ukazuju na to da postoji značajan negativan

\footnotetext{
${ }^{1}$ University of Belgrade, Faculty of Economics

${ }^{2}$ University of Belgrade, Faculty of Economics, zorica.mladenovic@ekof.bg.ac.rs
} 
dugoročni uticaj realnih zarada na stopu nezaposlenosti, i pozitivni dugoročni uticaj apresijacije realnog efektivnog deviznog kursa na realne plate. Da bi se dodatno smanjila stopa nezaposlenosti, potrebno je da se primene politike povećanja tražnje.

Ključne reči: nezaposlenost, efekat histerezisa, kointegracija, VAR model, dinamički odnosi

\section{Introduction}

This paper empirically investigates unemployment rate dynamics in Serbia. Two main issues are considered. Firstly, the empirical relevance of the unemployment hysteresis hypothesis is evaluated. Secondly, characteristics of dynamic relationship among unemployment rate and some key macroeconomic variables are determined and described. Our data set includes monthly information on real economic activity (real wages and industrial production index) and monetary policy (inflation rate and nominal/real exchange rate).

Empirical analyses of unemployment rate within macroeconometric framework have not been performed often for Serbia nor for the other countries in the Balkan region. The reasons for lack of macroeconometric literature for Serbia are numerous. The most important one is the short time span for time series analysis. Labour force survey (LFS) is conducted quarterly since 2014 by Statistical Office of Republic of Serbia (SORS). ${ }^{3}$ The number of unemployed persons reduced from 608 thousands in 2014 to 336 thousands in 2019. The unemployment rate was 19.2\% in 2014 and 10.4\% in 2019, (LFS data). Therefore, basic figures show significant improvements in the labour market in 2019 compared to 2014. The unemployment was falling due to better economic performance of Serbia. But, at the same time, Serbia is facing high emigration, which also reduces local unemployment rate.

Monetary policy in Serbia is based on the inflation targeting strategy. Over period $2014-2019$, average annual inflation rate was $1.9 \%$ (for example, $2.1 \%$ in 2014 and $1.9 \%$ in 2019). Inflation rate followed a path within the bands announced by the National bank of Serbia (NBS). Targeting the exchange rate is not the official goal of the monetary policy, although its level has been under the influence of the interventions from the National bank of Serbia. Nominal exchange rate exhibited changing trend that was characterized by depreciation during 2014-2016 period and mild appreciation over 2017-2019 period.

Investigating relationships between the unemployment and other nominal or real variables is a challenging task. Authors decided to contribute to the almost non-existent literature for Serbia, despite the awareness of all the constraints such analysis has. Presented findings are not only relevant for Serbia, but also

${ }^{3}$ LFS exists since 2008, when it was conducted semi-annually. Due to the change in methodology, data for period 2008-2013 are not comaprable with data from 2014 . 
for other countries in the Balkan region, since they face similar labour market problems.

The estimated model shows that real wages are determined by the real effective exchange rate, and the unemployment rate by real wages. Due to change in methodology in 2014, as well as changing trend in the unemployment rate, structural break in 2014 should be taken into account. Therefore, authors opted for shorter, but methodologically consistent time span, 2014-2019. In addition, the innovative methodology for hysteresis hypothesis testing, i.e. Fourier Augmented Dicky Fuller test is employed. This modelling approach, results obtained, as well as policy proposals, differ from Veselinović (2020), who recently examined the relationship among unemployment rate, interest rate and inflation rate for the period 2009-2019.

Procedure defined in Johansen (1996) and Juselius (2006), based on cointegrated vector autoregressive (CVAR) model, was implemented to explore the log-run behavior of the unemployment and its relationship with relevant macroeconomic variables. Prior to cointegration modelling, several unit root tests were performed to determine if the theory of unemployment hysteresis or the theory of natural rate of unemployment has empirical support.

The paper is structured as follows. Section 2 provides short literature review. Section Error! Reference source not found. presents research methodology. Data description and results of unit root test, as well as results of cointegration analysis, are reported in Section Error! Reference source not found.. Also, the same section contains discussion. Conclusions are summarized in Section 5 .

\section{Literature review}

Dynamics of the unemployment rate is important macroeconomic topic since it depends on key macro variables, such as GDP, industrial production, inflation rate, exchange rate, etc. Economic theory does not provide a single opinion on the evolution of the unemployment rate time series. Two influential theories of unemployment are: the natural rate of the unemployment theory (Friedman, 1968; Phelps, 1986) and the theory of unemployment hysteresis (Blanchard \& Summers, 1987). Alternative unemployment theories suggest different characteristics of the unemployment rate time series. The natural rate of unemployment theory predicts that the unemployment rate follows a path of fluctuating regularly around an equilibrium level. Such dynamics is usually associated with stationary time series. On the other side, theory of the unemployment hysteresis assumes high level of persistence, given the influence of unanticipated random shocks on the unemployment rate. Such a path often indicates the presence of at least one unit root.

Various versions of unit-root tests represent commonly used statistical framework for making discrimination between the two competing theories. Empirical studies have been conducted for a number of countries and regions. Some recent works include: Furuoka (2014, 2017a, 2017b), Ghoshray and 
Stamatogiannis (2015), Altuzarra (2015), Caporale, Gil-Alana and Lovcha (2016), Mladenović (2016), Jiang and Chang (2016), Alogoskoufis (2018) and Khraief, Shahbaz, Heshmati and Azam (2020).

Apart from univariate time series approach in examining unemployment rate dynamics, the multivariate set-up offered by VAR methodology has also been employed. It provides framework for modelling dynamic relationships among unemployment rate and other macroeconomic variables, so that influence of different economic policies on the unemployment can be assessed. Certain researches are shortly overviewed.

Anić and Mladenović (2014) found cointegration between unemployment rate and real wages in Serbia for the 2008-2013 period. In the long run, increase in real wages by $1 \%$ invoked the reduction of unemployment rate by $0.47 \%$. Variability of the unemployment rate was significantly explained by the variability of real wages.

Benazić and Rami (2016) estimated the influence of monetary policy on the unemployment in Croatia by using data from the period 1998-2014. The bounds testing approach of cointegration was employed. A rise in unemployment in the long-run is found to be due to the increase in prices and real exchange rate depreciation. It would be expected that depreciation of real effective exchange improves exports, causing increase in GDP and employment, but results show the opposite effect, i.e. depreciation would lead to even greater unemployment.

Dallari and Ribba (2020) investigated the effects that monetary and fiscal policies have on the unemployment in Greece, Ireland, Italy, Portugal and Spain. They used structural near-VAR model with the following variables: unemployment rate, inflation rate, government spending as the share of GDP, public debt and private debt (separately) as the share of GDP, spread defined as differential between the yield on 10-years domestic government bonds and the corresponding German bond. Period covered is Q1 2002 - Q3 2016 for Ireland and Q1 1999 - Q3 2016 for other countries. Two macroeconomic policies implications emerged. Expansionary monetary policies by European Central Bank can help the labour market in those countries, whereas fiscal policies conducted at national levels are not efficient stabilization tool.

\section{Research methodology}

This empirical study employs cointegrated VAR model (CVAR) framework as advanced in Johansen (1996) and Juselius (2006). CVAR is defined as follows:

$\Delta \mathrm{x}_{\mathrm{t}}=\Pi \mathrm{x}_{\mathrm{t}-1}+\Gamma_{1} \Delta \mathrm{x}_{\mathrm{t}-1}+\cdots+\Gamma_{\mathrm{k}-1} \Delta \mathrm{x}_{\mathrm{t}-\mathrm{k}+1}+\mu+\varepsilon_{\mathrm{t}}, \mathrm{t}=1, \ldots, \mathrm{T}$

where: $\mathrm{x}_{\mathrm{t}}$ is $p$-dimensional vector of $\mathrm{I}(1)$ variables, $k$ is the number of autoregressive lags included in unrestricted VAR model, $\Delta$ is the first difference operator, $\mu$ is $p$-dimensional vector of deterministic components, and $\varepsilon_{\mathrm{t}}$ is $p$ dimensional Gaussian white noise error component. The assumption that 
components of vector $x_{t}$ are cointegrated can be stated as follows (Johansen, 1996): $\Pi=\alpha \beta^{\prime}$, where $\alpha$ and $\beta$ are $p \times r$ matrices, $\mathrm{r} \leq \mathrm{p}$. Vector $\beta^{\prime} \mathrm{x}_{\mathrm{t}-1}$ contains $r$ cointegration (stationary) relations. Thus, the number of cointegration relations is $r$ and matrix $\beta$ is cointegration matrix. Parameters of matrix $\alpha$ are adjustment coefficients. They provide weights associated to cointegration relations in each equation of the model. Parameters of matrices $\Gamma_{i}(p \times p), i=$ $1,2, \ldots, k-1$, are often referred to as short-run parameters.

\section{Results and discussion}

Results are presented in the following three subsections. The first subsection provides graphical presentation of variables used, as well as the results of the unit root testing. The second and the third subsections present results of cointegration analysis. The second subsection summarizes results of CVAR modelling (4.2), whereas the third subsection reports results of modelling shortrun dynamics through equilibrium correction models and forecast error decomposition (4.3). Discussion follows results in subsection 4.4.

\subsection{Descriptive analysis and unit root test}

The main variable of interest is the unemployment rate, defined as the share of unemployed in active population aged 15+. Unemployment dynamics in Serbia is investigated by using monthly unemployment rate in period January 2014 December 2019. Monthly unemployment rate is constructed based on LFS quarterly data for the number of unemployed and active people. On the other side, National Employment Service (NES) ${ }^{4}$ collects data on registered unemployment at monthly level. Number of unemployed is disaggregated by proportional Denton temporal disaggregation method with related indicator series (Denton, 1971), and number of active is disaggregated without indicator series. Authors opted for the proportional Denton disaggregation method since this method is used for many EU countries. ${ }^{5}$

First picture in Figure 1 represents monthly unemployment rate that will be used in modelling. Baseline set of variables that could influence the unemployment are also captured by Figure 1. All variables are in log values and they are given (except the unemployment rate) as base indices (average 2014 is a base value). Variables considered are: consumer price index, nominal wage index, real wage index, nominal exchange rate index, real effective exchange rate index, and industrial production index. Variables that exhibit seasonal pattern are seasonally adjusted. Both, nominal exchange rate and real effective exchange rate are from NBS, whereas source for nominal wages, consumer

\footnotetext{
${ }^{4}$ http://www.nsz.gov.rs/live/dokumenti/statisti_ki_bilteni_nsz.cid667

5 Belgium, Bulgaria, Ireland, Spain, France, Cyprus, Malta, Poland, Slovenia and Slovakia, see http://ec.europa.eu/eurostat/cache/metadata/en/une_esms.htm
} 
price index and industrial production index is SORS. ${ }^{6}$ First visual inspection shows that probably all series are unit-root processes. Authors performed ADF unit root test for level and first difference in order to examine if series used are stationary. ADF test statistics for unemployment rate amounted 0.14 for level and -4.95 for first difference (the $5 \%$ critical value -2.86 ). Therefore, authors conclude that first difference of unemployment rate is stationary. Also, first differences of all other series are stationary, whereas levels have one unit root. ${ }^{7}$

Figure 1 Variables used, log values, 2014-2019
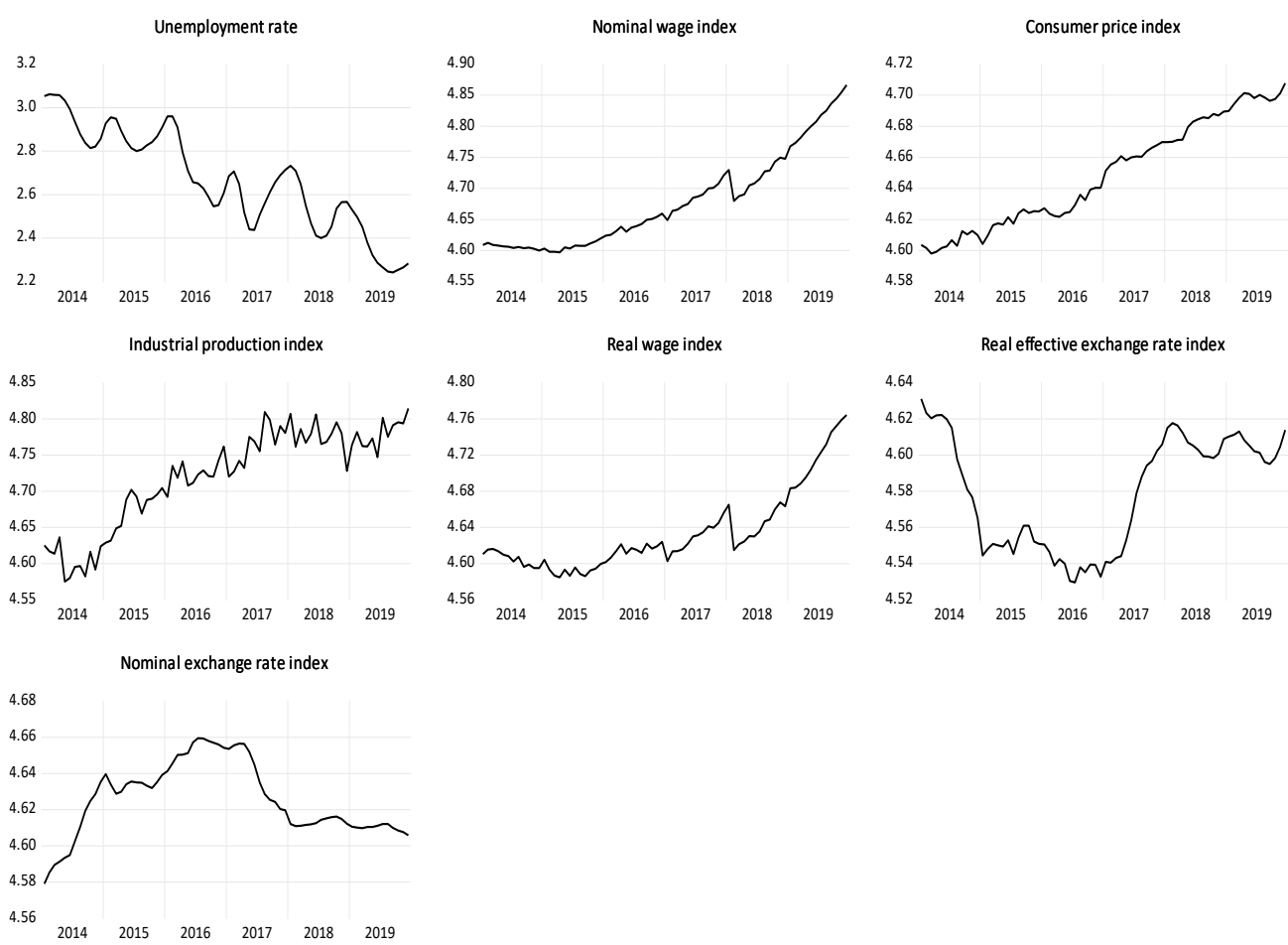

Source: Authors' calculation

It may be observed that unemployment rate exhibits peculiar non-linear trend. Conventional unit root test, like the ADF test, assume constant deterministic components over time. To capture the deterministic component in a less restricted way, authors follow Enders and Lee (2012a, 2012b), who have

${ }^{6}$ According to the methodology of National bank of Serbia upward trend in real effective exchange rate implies real appreciation, whereas downward trend is a sign of real depreciation.

7 Results for ADF unit root tests for all time series are available upon request. We skipped those results due to space limits. 
advanced a unit root test using the Fourier form that encompasses several smooth structural changes (the FADF test). The specification of deterministic component enables unit root testing without an a priori design of the exact form of the trend. The results are mixed regarding the significance of the new deterministic component. Nevertheless, both versions of test (with single and cumulative frequencies) suggest that level of the unemployment rate is nonstationary, whereas first difference is stationary (Table 1). Therefore, it can be concluded that the first difference of the unemployment rate is stationary according to both ADF and FADF unit root tests.

Table 1. FADF unit root test

\begin{tabular}{|c|c|c|c|c|c|c|c|}
\hline & $\begin{array}{l}\text { Minimum } \\
\text { residual } \\
\text { sum squared }\end{array}$ & FADF & $\begin{array}{l}\text { FADF } \\
\text { critical } \\
\text { value }\end{array}$ & $L$ & $\begin{array}{l}\text { Frequency: } \\
\text { Number and type }\end{array}$ & $\mathrm{F}$ test & $\begin{array}{l}\mathrm{F} \\
\text { critical } \\
\text { value }\end{array}$ \\
\hline ur & 0.011415 & -3.49 & \multirow[t]{2}{*}{-4.05} & 10 & \multirow[t]{2}{*}{2 (Single) } & 3.2 & 9.14 \\
\hline$\Delta u r$ & & -5.66 & & 7 & & & \\
\hline ur & 0.002071 & -4.84 & \multirow[t]{2}{*}{-6.86} & 14 & \multirow[t]{2}{*}{5 (Cumulative) } & 15.47 & 9.14 \\
\hline$\Delta u r$ & & -8.11 & & 12 & & & \\
\hline
\end{tabular}

Note: Impulse dummy variable for 2018:10 was included for the FADF test with single frequency. Significance of the Fourier expansion term is based on the $F$ test. The critical values for both FADF and $\mathrm{F}$ tests refer to the $5 \%$ significance level and $\mathrm{T}=100$, as given by Enders and Lee (2012b). The number of frequencies is chosen according to the minimum value of the residual sum of squares.

Source: Authors' calculus

\subsection{Cointegration in system framework}

Authors investigated several VAR systems with different set of variables presented in section $4.1 .{ }^{8}$ The first model is the four variable VAR system containing following variables: the unemployment rate (un), nominal wage index (w), the consumer price index (cp) and the industrial production index (ip). This and all other specifications include linear trend (t) as a part of the cointegration space with the structural break occurred in 2018:1. Shift in a trend is associated with the changing dynamics of wage index variable (Figure 1). The break in wage series in January 2018 is due to the change in statistical methodology of calculating wages. ${ }^{9}$ Testing on the long-run exclusion indicates that the industrial production index does not belong to the cointegration space.

As a consequence, authors excluded industrial production index variable from the further analysis. Instead, nominal exchange rate index (ex) is included. Within the new framework, consumer price index is now identified as a variable that should not be a part of cointegration space. Given the preliminary analysis

\footnotetext{
8 Due to space limit we presented only results for final model. Results for other investigated models are available upon request.

9 For detail see Change of data sources and methodology for calculating average salaries and wages https://www.stat.gov.rs/en-US/vesti/20180226-promena-izvorapodataka-i-metodologije-za-izracunavanje-prosecnih-zarada
} 
conducted, authors have decided to slightly modify the variable set by including real wage index (rw), instead of nominal wage index and real effective exchange rate (rex), instead of nominal exchange rate. This way, authors still capture information about price index dynamics, although they do not explicitly include it in our model. Therefore, the third and final specification contains the following three variables: unemployment rate, real wage index and real effective exchange rate index.

The key characteristics of model 3 are summarized as follows: a) Number of lags is $5, b)$ Deterministic component is linear trend restricted to be a part of cointegration space and c) Linear trend in cointegration space is piecewise, with the break occurred in 2018:1. It is captured by dummy variable DT introduced as follows: DT = \{t, for period: January 2018 - December 2019; 0, otherwise\}.

Results given in

Table 2 show that two cointegrating vectors are found. All variables belong to the system and none of them is stationary, as reported in Table 3. Estimated cointegrating and adjustments vectors and provided by Table 4 and Table 5.

Table 2. Testing for cointegration

\begin{tabular}{|l|l|l|l|l|}
\hline Hypotheses & Eigenvalue & Trace test & $\mathrm{C}_{95 \%}(\mathrm{p}-\mathrm{r})$ & $\mathrm{p}$-value \\
\hline $\mathrm{H}_{0}: \mathrm{r}=0, \mathrm{H}_{1}: \mathrm{r}>0$ & 0.690 & 135.16 & 57.11 & 0.00 \\
\hline $\mathrm{H}_{0}: r=1, \mathrm{H}_{1}: r>1$ & 0.522 & 56.63 & 35.36 & 0.00 \\
\hline $\mathrm{H}_{0}: \mathrm{r}=2, \mathrm{H}_{1}: \mathrm{r}>2$ & 0.102 & 7.22 & 17.50 & 0.63 \\
\hline
\end{tabular}

Note: Number of cointegrated vectors is denoted by $r$. VAR of order 5 is used. Four dummy variables are included: D1 takes only non-zero value 1 for 2017:1; D2 is equal to 1 for 2018:1, -1 for 2018:2 and 0 otherwise; D3 has only non-zero value 1 for 2015:2; D4 takes only non-zero value 1 for 2017:4

Source: Authors' calculus

Table 3. Testing long-run exclusion and stationarity

\begin{tabular}{|c|c|c|c|c|c|l|}
\hline \multicolumn{7}{|c|}{ Testing a zero row in cointegrated vectors } \\
\hline$R$ & Test-statistic $\chi_{2}^{2}$ & \multicolumn{1}{|c|}{ un } & rw & rex & trend & Break in trend \\
\hline 2 & The 5\% c.v. 5.99 & 42.52 & 36.73 & 9.09 & 43.25 & 40.33 \\
\hline \multicolumn{7}{|c|}{ Testing stationarity (testing a unit cointegrating vector) } \\
\hline$R$ & Test-statistic $\chi_{3}^{2}$ & un & rw & rex & & \\
\hline 2 & The 5\% c.v. 7.81 & 29.74 & 49.15 & 43.81 & & \\
\hline
\end{tabular}

Source: Authors' calculus

Table 4. Estimated cointegration vectors (transposed)

\begin{tabular}{|l|l|l|l|l|l|}
\hline Vector & un & rw & rex & T & DT \\
\hline Beta 1 & 0.042 & 1 & -0.316 & -0.002 & -0.005 \\
\hline Beta 2 & 1 & 0.492 & 0.181 & 0.012 & 0.006 \\
\hline
\end{tabular}

Source: Authors' calculus 
Table 5. Estimated adjustment coefficients

\begin{tabular}{|c|l|l|}
\hline Equation for & Alfa 1 & Alfa 2 \\
\hline$\Delta u n$ & $\mathbf{- 0 . 2 2 2 ( - 2 . 1 8 )}$ & $\mathbf{- 0 . 3 3 7 ( - 7 . 8 9 0 )}$ \\
\hline$\Delta r w$ & $\mathbf{- 0 . 3 0 7 ( - 1 0 . 6 5 )}$ & $\mathbf{0 . 0 2 4 ( 2 . 0 1 4 )}$ \\
\hline$\Delta r e x$ & $0.001(0.022)$ & $-0.016(1.129)$ \\
\hline
\end{tabular}

Source: Authors' calculus

Having two or more cointegrated vectors in a system, any linear combination of them will be stationary. Therefore, it is necessary to identify cointegration space, so that it becomes either exactly identified or overidentified (cf. Johansen, 1996). Under the two cointegrating vectors, the identification scheme assumes the imposition of at least one zero restriction on parameters in each vector. By looking at the estimated values, it may be concluded that the unemployment rate should be excluded from the first vector. The conclusion is not obvious for the second vector.

To make plausible restrictions on cointegration parameters, it is of interest to consider estimated adjustment vectors. The first cointegrating vector is highly significant in both equations, for the first difference of real wages and unemployment rate. The second cointegrating vector suggests that unemployment rate and real wages are equilibrium-correcting to the second cointegrating vector as well. No significance of the adjustment coefficients is found for real effective exchange rate, suggesting its weak exogeneity. The formal assessment is based on testing for zero restrictions on both adjustment coefficients in the equation for the first difference of real effective exchange rate. The restrictions are statistically accepted: $\chi_{2}^{2}=1.13(0.57)$. Estimated cointegration vectors now read as follows (Table 6):

Table 6. Estimated cointegration vectors under the imposed zero restrictions on adjustment coefficients

\begin{tabular}{|l|l|l|l|l|l|}
\hline Vector & un & rw & rex & t & DT \\
\hline Beta 1 & 0.043 & 1 & -0.316 & -0.002 & -0.005 \\
\hline Beta 2 & 1 & 0.562 & 0.092 & 0.012 & 0.005 \\
\hline
\end{tabular}

Source: Authors' calculus

As before, the first cointegrating vector seems to describe the long-run comovement between real wages and real effective exchange rate. The second cointegrating vector now has more transparent interpretation, as it probably explains long-run relationship between unemployment rate and real wages. By imposing zero restriction on the unemployment rate in the first vector and on real effective exchange rate in the second vector, while keeping zero 
restrictions of real exchange rate adjustment coefficients, the following estimations are reached (Table 7 and Table 8):

Table 7. Estimated cointegration vectors (transposed)

\begin{tabular}{|c|c|c|c|c|c|}
\hline Vector & un & rw & rex & $t$ & DT \\
\hline Beta 1 & 0 & 1 & $-0.327(-3.58)$ & $-0.003(-9.47)$ & $-0.006(-11.11)$ \\
\hline Beta 2 & 1 & $0.843(1.97)$ & 0 & $0.011(13.70)$ & $0.004(1.55)$ \\
\hline
\end{tabular}

Source: Authors' calculus

Table 8. Estimated adjustment coefficients

\begin{tabular}{|c|l|l|}
\hline Equation for & Alfa 1 & Alfa 2 \\
\hline$\Delta u n$ & $-0.117(-1.21)$ & $\mathbf{- 0 . 3 5 7}(\mathbf{- 8 . 4 8 3 )}$ \\
\hline$\Delta r w$ & $\mathbf{- 0 . 3 0 1 ( - 1 0 . 5 8 )}$ & $0.005(0.414)$ \\
\hline$\Delta r e x$ & 0 & 0 \\
\hline
\end{tabular}

Note: t-values are in parentheses and significant coefficients in bold.

Source: Authors' calculus

Thus, the three-variable system consists of two long-run relationships. The first one is the cointegration relationship between real wages and real effective exchange rate. Real appreciation of $1 \%$ leads to the increase of real wages by $0.33 \%$. Each month, about $30 \%$ of the real wage dynamics is corrected towards the equilibrium relationship with real exchange rate. The second cointegrating vector implies that, in the long-run, the unemployment rate and real wages are co-moving. If real wages increase by $1 \%$, then unemployment rate will decline by $0.84 \%$. About $36 \%$ of unemployment rate dynamics is corrected each month according to the cointegration path with real wages. The presence of linear trend in both cointegration vectors captures the effects of other variables that are not directly included in our system, e.g. economic variables, labour market institutions, duality of Serbian labour market, etc. Autonomous fall in unemployment rate is described by the trend estimation -0.011 that has dropped to -0.015 since January 2018 as confirmed by break in the linear trend function (estimate is -0.004).

The evidence of two stationary relations implies that there is one independent common stochastic trend in the data that causes the non-stationary behavior. The finding of real effective exchange rate being weakly exogenous suggests that the stochastic trend in this variable is the common trend (cf. Juselius, 2006). Thus, the loading of the common trend in each equation shows the impact of accumulated unexpected random shocks of real effective exchange rate. The loading is estimated to be negative $(-2.76)$ in the unemployment rate equation. For the real wages and the real effective exchange rate the loadings are estimated to be positive (3.27 and 9.99 respectively). 
Statistical performances of final VAR model are analysed by univariate and multivariate test statistics. Residuals do not exhibit autocorrelation and are normally distributed. ${ }^{10}$

\subsection{Modelling short-run dynamics}

Bearing in mind the results of cointegration analysis, authors estimated individual equilibrium correction models $(E C M)$ for the unemployment rate (equation 2) and real wages (equation 3). Equilibrium correction components are represented by the estimated cointegrated vectors: $E C M 2=u n+0.85 \mathrm{rw}-$ $0.011 t-0.004 D T$ and $E C M 1=r w+0.33 r e x+0.003 t+0.006 D T$. We opt for a single-equation approach to achieve more efficient estimations by eliminating redundant lagged variables that appear in CVAR model.

$$
\begin{gathered}
\Delta u n_{t}=2.24-0.33 E C M 2_{t-1}+1.06 \Delta u n_{t-1}-0.36 \Delta u n_{t-3}+0.45 \Delta u n_{t-4} \\
(6.27)(-6.28) \quad(14.62) \quad(-3.38) \quad(4.49) \\
+0.72 \Delta r w_{t-1}+0.8 \Delta r w_{t-2}+0.72 \Delta r w_{t-3}+0.59 \Delta r w_{t-4}+0.8 \Delta r e x_{t-4}
\end{gathered}
$$

$\mathrm{R} 2=0.87, \mathrm{~s}=0.0189, \mathrm{AR}(12)=17.50(0.13), \mathrm{JB}=1.36(0.51), \mathrm{ARCH}(6)=9.09(0.17)$, RESET $=1.08(0.20)$

$$
\begin{aligned}
\Delta r w_{t} & =0.84-0.27 E C M 1_{t-1}-0.24 \Delta r w_{t-1}-0.21 \Delta r e x_{t-1}-0.18 \Delta r e x_{t-3} \\
& (9.69)(-9.67) \\
(-3.77) & (-2.08)
\end{aligned}
$$

$R 2=0.78, \mathrm{~s}=0.0046, \mathrm{AR}(12)=16.21(0.18), \mathrm{JB}=1.82(0.40), \mathrm{ARCH}(6)=9.94(0.13)$, RESET $=0.75(0.39)$ Note: $t$ values in parenthesis. The regression standard error is denoted by s. Both equations contain
step dummy variable that takes non-zero value 1 from $2018: 1$ to $2019: 12$. Its presence is due to
the specification of the CVAR model given a trend-shift within cointegration space. ECM for real
wages also includes dummy variables D1 and D2. The following test-statistics are presented: JB is
the Jarque-Bera test statistic for the disturbance term normality; AR(12) is a Lagrange multiplier
test-statistic for the twelveth-order autocorrelation, ARCH(6) is the Lagrange multiplier test-statistic
for the sixth-order autocorrelation in the squared disturbance terms, and RESET is the model
specification test. The p-value is given in (.) after a statistic.

The estimated equations do not display any sign of misspecification. Substantial portion of variability of each variable is explained by the estimated model. The estimated adjustment coefficients $(-0.33$ and -0.27$)$ are close to the values provided by the Johansen approach.

The unemployment rate equation shows that the unemployment rate is strongly adjusting to the long-run relation with real wages, with one-third of disequilibrium corrected each month. The short-run structure is described by the first difference of real wages lagged one to four periods, the first difference

${ }^{10}$ Results are available upon request. We skipped those statistics due to space limits. 
of the real effective exchange rate lagged four periods and the first difference of the unemployment rate with lags one, three and four. Such a large number of explanatory variables indicates strong influence of inertia factors, especially from real wages.

The real wages equation suggests that $28 \%$ of growth in real wages is corrected by the long-run relation between real wages and real effective exchange rate. The short-run dynamics is represented only by the first difference of real wages lagged one period and the first difference of real effective exchange rate lagged one and three periods. Unemployment rate was not found to play significant role in explaining short-term structure for the real wages equation.

Given the significant long-run impact of real wages to unemployment rate, we further consider how the real wages shocks affect unemployment rate throughout time. These dynamic effects are calculated from the forecast error variance decomposition based on estimated VAR model that corresponds to CVAR specification used in 4.2. Cholesky decomposition of the covariance matrix is calculated from the following two orderings: (1) real effective exchange rate - real wages - unemployment rate and (2) real wages - real effective exchange rate - unemployment rate. Results for ordering (1) are given in Table 9.

Table 9. Forecast error variance decomposition of real effective exchange rate, real wages and unemployment rate (\%) - ordering (1)

\begin{tabular}{|c|c|c|c|c|c|c|c|c|c|}
\hline \multirow[t]{3}{*}{ Months } & \multicolumn{3}{|c|}{$\begin{array}{l}\text { Real effective } \\
\text { exchange rate }\end{array}$} & \multicolumn{3}{|c|}{ Real wages } & \multicolumn{3}{|c|}{ Unemployment rate } \\
\hline & \multicolumn{3}{|c|}{ Shock to: } & \multicolumn{3}{|c|}{ Shock to: } & \multicolumn{3}{|c|}{ Shock to: } \\
\hline & rex & rw & un & rex & rw & un & rex & Rw & Un \\
\hline 1 & 100.0 & 0.0 & 0.0 & 19.4 & 80.6 & 0.0 & 2.5 & 2.5 & 95.0 \\
\hline 4 & 96.2 & 3.4 & 0.4 & 34.5 & 64.7 & 0.8 & 12.4 & 0.8 & 86.8 \\
\hline 8 & 93.4 & 5.5 & 1.1 & 44.1 & 53.1 & 2.8 & 35.4 & 2.7 & 61.9 \\
\hline 12 & 91.9 & 5.9 & 2.2 & 50.8 & 46.5 & 2.7 & 50.5 & 5.3 & 44.2 \\
\hline 24 & 91.5 & 6.2 & 2.3 & 55.0 & 42.7 & 2.3 & 47.7 & 7.4 & 44.9 \\
\hline 36 & 91.5 & 6.2 & 2.3 & 54.3 & 43.4 & 2.3 & 46.7 & 9.3 & 44.0 \\
\hline
\end{tabular}

Note: values in rows for each variable sum to $100 \%$.

Source: Authors' calculus

When looking at the decomposition of the unemployment rate, the contribution of own shocks is about $62 \%$ after 8 months, but drops to $44 \%$ with higher horizon. After three years, the variability of the unemployment rate is due to the variability of real wages and real effective exchange rate by $56 \%$ ( $9 \%$ and $47 \%$, respectively). The variability of real wages is dominantly explained by shocks in real effective exchange rate (54\%) and by its own shocks (43\%). The variability of real effective exchange rate is almost all due to its own shocks. 
Results remain basically the same when ordering (2) is applied. The key difference is a relative contribution of shocks to real wages and real effective exchange rate in the variability of the unemployment rate. Portions of both real wages and real effective exchange rate are almost equal explaining in total $56 \%$ of unemployment rate variability after 24 months. These numbers slightly change after 36 months with shares of $26 \%$ and $30 \%$ for real wages and real effective exchange rate respectively.

\subsection{Discussion}

The presence of real effective exchange rate in the real wage equation usually accounts for competitive pressures that come from foreign producers. There are several channels advanced in the literature (cf. Camarero, Adamo and Tamarit, 2019) that explain the way real effective exchange rate may affect real wages. Some of them assume that currency depreciation (drop in real effective exchange rate) and real wages move in the opposite direction, but others imply the same type of trend in currency depreciation and real wages. Opposite movement is put forward by labour demand channel (currency depreciation increases the demand for domestic goods, thus causing labour demand and real wages to raise) and "wage bargaining pressure channel" (currency depreciation makes imported final goods more expensive, which put increasing wage pressure from workers that try to keep their real net incomes at the same level). Movement in the same direction is expected from "imported intermediate goods channel" (depreciation increases the price of imported intermediate goods and production costs which may result in a fall of labour demand and in the real wages) and "imported inflation channel" (real currency depreciation makes prices of imported goods higher, thus causing increase of the consumer price index and reduction of real wages). Final effects of real effect exchange rate on real wages heavily depends on institutional-set up in a given economy (Camarero et al., 2019).

The long-run relationship between real exchange rate and real wages has been empirically supported for the Serbian economy across different subperiods and various economic and political frameworks (Petrović and Vujošević, 2000; Arsić, Mladenović and Petrović, 2001; Arsić et al., 2005). Authors' findings for the recent period are due to the combination of both imported effects channels. The presence of real effective exchange rate also accounts for the overall macroeconomic effects, given the long history of high vulnerability of the Serbian economy to the shocks in the exchange rate.

The strong long-run association of real wages and unemployment rate in Serbia was also detected for earlier period 2008-2013 (Anić \& Mladenović, 2014). The unemployment rate is only equilibrium-adjusting in both 2008-2013 and 20142019 period. The absence of adjustment from real wages implies that real wages do not fully capture the effects from the labour market. However, finding of cointegration between the unemployment rate and real wages, along with 
the result that the unemployment rate is non-stationary, indicates that demandside measures may be helpful in further decline of unemployment.

Concerning monetary variables, indirect long-run role of real effective exchange rate is estimated. The relevance of real effective exchange rate in describing unemployment rate dynamics can be compared with the findings for neighbouring Croatia during 1998-2014 period (Benazić \& Rami, 2016). In both countries, Serbia and Croatia, the unemployment rate negatively reacts to real currency appreciation. For the success of the policy aiming at reducing unemployment rate in Serbia, the suggestion is that real depreciation should be avoided.

\section{Conclusions}

Authors' cointegration analysis reveals two long-run relations among variables considered. The first one positively associates real wages with real effective exchange rate. Only real wages are equilibrium correcting, i.e. real effective exchange rate is weakly exogenous variable with respect to cointegration parameters. Estimated cointegrated parameter implies that real currency depreciation will trigger a fall of real wages, and that real currency appreciation will cause a rise of real wages. The second cointegration relation describes long-run co-movement between real wages and unemployment rate, such that unemployment rate is equilibrium adjusting. Real wages are weakly exogenous variable with respect to the cointegration parameters. Contrary to wage equations often estimated in the empirical studies, authors have found no simultaneity between real wages and the unemployment rate. The estimated relationship points to negative influence of real wages: increase of real wages will make unemployment rate lower, whereas a decline of real wages will increase the unemployment rate.

It may be argued that the unemployment rate is under the direct long-run impact from real wages and under the indirect influence from real effective exchange rate. This direct effect of real wages on the unemployment rate is expected and often found in the empirical literature given that real wages represent labour cost.

Indirect long-run influence from real exchange rate to unemployment rate is transmitted through the real wages. According to the estimated cointegrated parameters in both relations, this impact is derived to be negative. The same is confirmed by a common trend analysis that provides alternative insight into the cointegration framework. It indicates that cointegrated system is characterized by one common trend being identified as accumulated shocks in real effective exchange rate. Their impact on real wages is found to be positive, and negative when unemployment rate is considered.

Our short-run analysis derived from ECM models again highlights the importance of real wages and real effective exchange rate in describing unemployment rate dynamics. 
The results of forecast error variance decomposition (ordering: real exchange rate - real wages - unemployment rate) suggest that the variability of the unemployment rate is in large portion explained by shocks in real wages and real effective exchange rate when horizon longer than 8 months is considered. Relative share of real wages and real effective exchange rate in the variability of the unemployment rate changes in favour of real wages with the Cholesky ordering, which puts real wages in the first place. Nevertheless, the total share of both variables remains the same.

\section{References}

Alogoskoufis, G. (2018). The Clash of Central Bankers with Labour Market Insiders, and the Persistence of Inflation and Unemployment. Economica, 85(337), 152-176. https://doi.org/10.1111/ecca.12241

Altuzarra, A. (2015). Measuring Unemployment Persistence by Age and Gender. Romanian Journal of Economic Forecasting, XVIII(4), 110-133.

Anić, A., \& Mladenović, Z. (2014). Econometric modelling of unemployment in Serbia during period 2008-2013. Yugoslav Journal of Operations Research, 24(3), 333346. https://doi.org/10.2298/YJOR140430026A

Arsić, M., Mladenović, Z., Nojković, A., \& Petrović, P. (2005). Makroekonometrijsko modeliranje privrede Srbije: teorijske osnove i rezultati. Belgrade: CES MECON.

Arsić, M., Mladenović, Z., \& Petrović, P. (2001). Macroeconomic Stabilization in the FRY.

Benazić, M., \& Rami, J. (2016). Monetary policy and unemployment in Croatia. Economic Research-Ekonomska Istraživanja, 29(1), 1038-1049. https://doi.org/10.1080/1331677X.2016.1211955

Blanchard, O. J., \& Summers, L. H. (1987). Hysteresis in unemployment. European Economic Review, 31, 288-295. https://doi.org/10.1093/oxrep/grr018

Camarero, M., Adamo, G. D., \& Tamarit, C. (2019). Differences in wage determination in the Eurozone: A challenge to the resilience of the common currency. Journal of Policy Modeling, Advance on. https://doi.org/10.1016/j.jpolmod.2019.09.006

Caporale, G. M., Gil-Alana, L. A., \& Lovcha, Y. (2016). Testing unemployment theories: A multivariate long memory apporach. Journal of Applied Economics, XIX(1), 95112. https://doi.org/10.1080/00036846.2013.815311

Dallari, P., \& Ribba, A. (2020). The dynamic effects of monetary policy and government spending shocks on unemployment in the peripheral Euro area countries. $\begin{array}{llll}\text { Economic } \quad \text { Modelling, 2019), } & \text { 218-232. }\end{array}$ https://doi.org/10.1016/j.econmod.2019.05.018

Denton, F. T. (1971). Adjustment of monthly or quarterly series to annual totals: An approach based on quadratic minimization. Journal of the American Statistical Association, 66(333), 99-102. https://doi.org/10.1080/01621459.1971.10482227

Enders, W., \& Lee, J. (2012a). A unit root test using a Fourier series to approximate smooth breaks. Oxford Bulletin of Economics and Statistics, 74(4), 574-599. https://doi.org/10.1111/j.1468-0084.2011.00662.x

Enders, W., \& Lee, J. (2012b). The flexible Fourier form and Dickey-Fuller type unit root tests. Economics Letters, 117(1), 196-199. https://doi.org/10.1016/j.econlet.2012.04.081

Friedman, M. (1968). The Role of Monetary Policy. The American Economic Review, $58(1), 1-17$. 
Furuoka, F. (2014). Are unemployment rates stationary in Asia-Pacific countries? New findings from Fourier ADF test. Economic Research-Ekonomska Istraživanja, 27(1), 34-45. https://doi.org/10.1080/1331677X.2014.947105

Furuoka, F. (2017a). A new approach to testing unemployment hysteresis. Empirical Economics, 53(3), 1253-1280. https://doi.org/10.1007/s00181-016-1164-7

Furuoka, F. (2017b). A new test for analysing hysteresis in European unemployment. $\begin{array}{llll}\text { Applied Economics } \quad \text { Letters, } & \text { 24(15), }\end{array}$ https://doi.org/10.1080/13504851.2016.1257209

Ghoshray, A., \& Stamatogiannis, M. P. (2015). Centurial evidence of breaks in the persistence of unemployment. Economics Letters, 129, 74-76. https://doi.org/10.1016/j.econlet.2015.02.012

Jiang, Y., \& Chang, T. (2016). Bring Quantile Unit Root Test Back in Testing Hysteresis in Unemployment for the United States. Romanian Journal of Economic Forecasting, XIX(1), 5-13.

Johansen, S. (1996). Likelihood Based Inference in Cointegrated Vector Autoregressive Models. Oxford University Press.

Juselius, K. (2006). The Cointegrated VAR Model: Methodology and Applications. (M. Arellano, G. Imbens, G. E. Mizon, P. Adrian, \& M. Watson, Eds.). Oxford: Oxford University Press.

Khraief, N., Shahbaz, M., Heshmati, A., \& Azam, M. (2020). Are unemployment rates in OECD countries stationary? Evidence from univariate and panel unit root tests. North American Journal of Economics and Finance, 51(March 2018), 100838. https://doi.org/10.1016/j.najef.2018.08.021

Mladenović, Z. (2016). Econometric Testing of Unemployment Hysteresis in Selected CEE Countries: Lessons for the Serbian Economy. Ekonomika Preduzeća, 403413.

Petrović, P., \& Vujošević, Z. (2000). Monetary accommodation in transition economies: econometric evidence from Yugoslavia 's high inflation in the 1980s. Journal of Development Economics, 62, 495-513.

Phelps, E. S. (1986). Money-Wage Dynamics and Labor Market Equilibrium. Journal of Political Economy.

Veselinović, N. (2020). Monetary policy and unemployment in the Republic of Serbia. Industrija, 48(2), 73-88. https://doi.org/10.5937/industrija48-25210 